\title{
Modelling the Impact of Changes in the Interest Rates on the Economy: An Austrian Perspective
}

\section{P le Roux and B Ismail}

\section{Department of Economics, University of Port Elizabeth :Vista Campus}

\begin{abstract}
Even though econometric models and yield curve analysis are useful in assessing the impact of interest rate changes on the economic structure, their power to predict the magnitude and direction of swings in the business cycle is often restricted to the use of short-term interest rates. From an Austrian school perspective on interest rates, empirical evidence suggests that the profitability of heavy industries further downstream outperforms that of light industries in the initial stages of monetary easing, due to a rising demand for investment goods and a rise in capacity utilisation levels. This paper assesses the impact of interest rates changes on the productive structure of the economy by taking into account the effect thereof on sector earnings and ultimately share prices.
\end{abstract}

JEL E43, 52; N10

\section{INTRODUCTION}

Conventional economic analysis assesses the impact of interest rate changes on the economy by evaluating its impact on the demand-side of the economy, and possibly potential output. It is argued that a reduction in interest rates increases liquidity, lowers the cost of consumption and induces an increase in aggregate demand. This demand expansion should lead to secondary effects such as accelerated investment and employment growth, so inducing a multiplier process in the economy. Eventually, rising prices will reduce the real pool of funds, placing upward pressure on interest rates and bringing about a new equilibrium.

Conventional economic theory also suggests that lower interest rates will directly increase investment spending by lowering the cost of capital. In addition, it should raise production capacity and thus potential future output growth. The level of the new equilibrium for output, inflation and interest rates will depend on how the induced imbalances are corrected. Relatively low 
interest rates will lead to sizeable potential output growth via an interest-elastic investment demand function, ensuring adequate wealth creation to accommodate rising demand.

However, if investment does not respond adequately to lower interest rates and higher anticipated demand growth, wealth creation falls behind rising claims on the economy. Pressure on prices and the current account builds up. This would induce rising interest rates, with the end result that the demand/supply equilibrium could very well be established at the same level of output than before. This is unfortunate, as the goal in any economy would be to establish a new equilibrium at a higher level of output, by ensuring that lower interest rates shift both the demand and supply curves to the right. A precondition for this to happen is high interest rate elasticity of investment demand. The sensitivity of investment to interest rates is therefore crucial to the potential impact of interest rate changes on the economy.

Empirical evidence suggests that, in South Africa, private investment is more responsive to long-term interest rates than to short-term interest rates. As Figure 1 below clearly indicates, the transmission mechanism between a decline in long-rates and a higher level of investment is rather long.

\section{Figure 1 Investment and long-term interest rates}

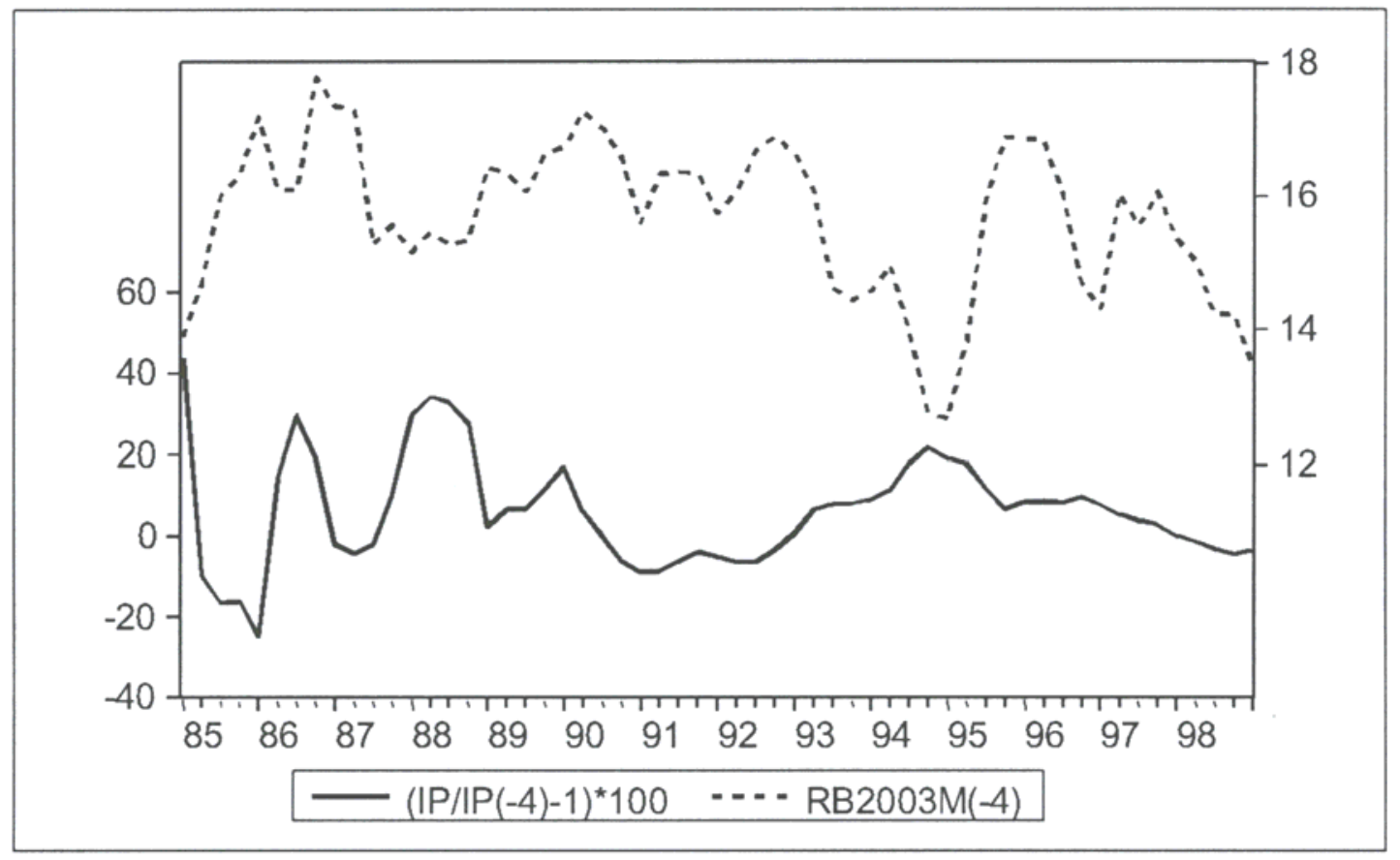




\section{Table 1 Regression results of investment function}

Dependent variable is real non-residential private investment

Sample (adjusted): 1986:1 1999:1

Included observations: 53 (after adjusting endpoints)

\begin{tabular}{|l|c|c|c|c|}
\hline Variable & Coefficient & Std. error & $\begin{array}{l}\text { t-statis- } \\
\text { tic }\end{array}$ & Prob. \\
\hline Dummy for 1986Q1 & 4453 & 1398 & 3.185 & 0.003 \\
\hline Lagged dependent variable & 0.854 & 0.044 & 19.39 & 0.000 \\
\hline $\begin{array}{l}\text { Polynomial lag of long-term interest } \\
\text { rates }\end{array}$ & -200.7 & 63.6 & -3.156 & 0.003 \\
\hline Polynomial lag of domestic demand & 0.011 & 0.003 & 3.539 & 0.001 \\
\hline R-squared & 0.98 & $\begin{array}{l}\text { Mean dependent } \\
\text { var }\end{array}$ & 44188 \\
\hline Adjusted R-squared & 0.98 & $\begin{array}{l}\text { S.D. dependent } \\
\text { var }\end{array}$ & 9959 \\
\hline S.E. of regression & 1312 & $\begin{array}{l}\text { Akaike info } \\
\text { criterion }\end{array}$ & 14.43 \\
\hline Sum squared resid & 84323439 & Schwarz criterion & 14.58 \\
\hline Log likelihood & -454 & F-statistic & 982.65 \\
\hline Durbin-Watson stat & 1.38 & Prob (F-statistic) & 0 \\
\hline
\end{tabular}

\section{Figure 2 Goodness-of-fit of investment regression}

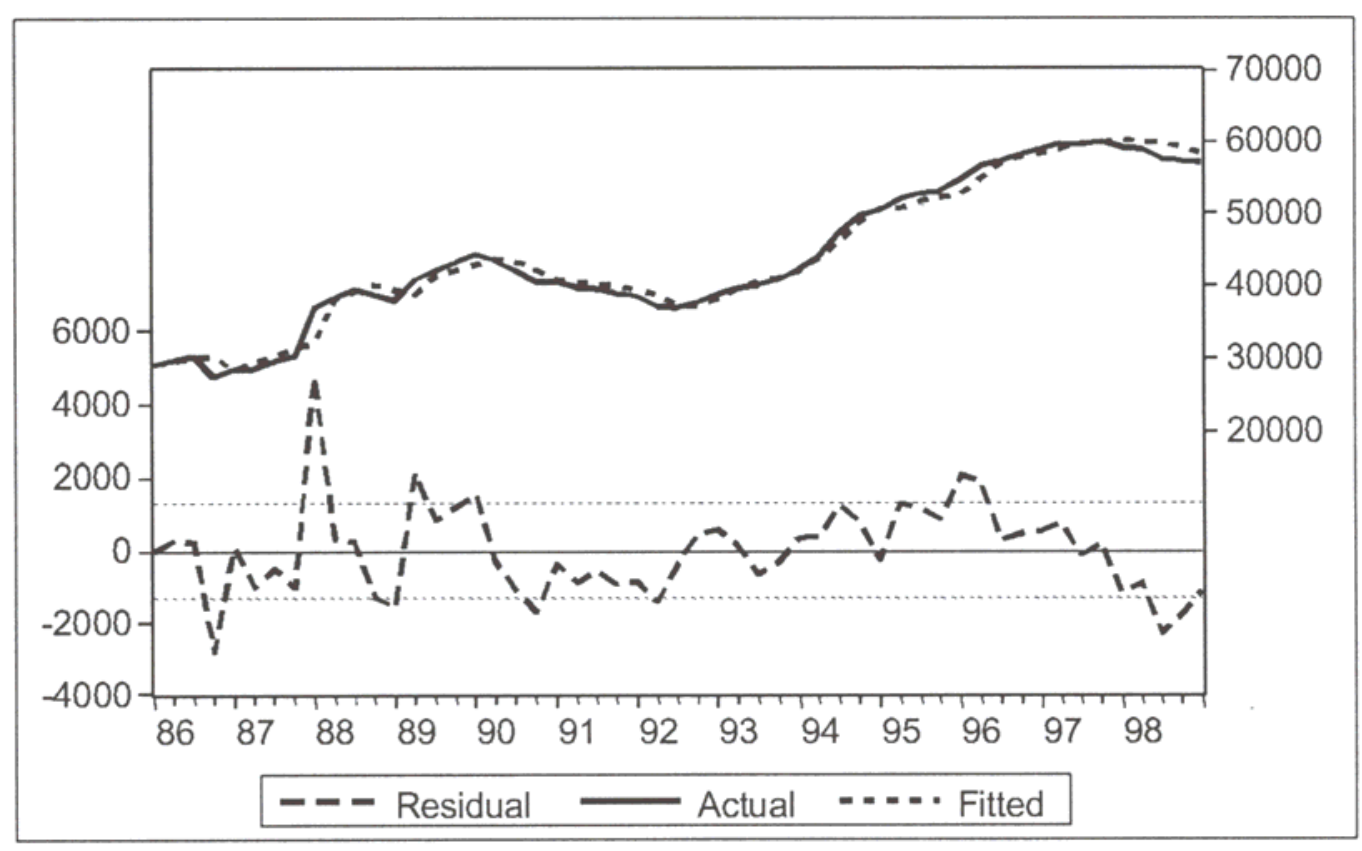

Over a thirteen-year period, South Africa's investment function also shows considerable instability, making it even more difficult to model the impact of 
lower interest rates on investment and macroeconomic balance. Table 1 and Figure 2 above show the regression results of non-residential private investment as a function of long-term interest rates and domestic demand (GDE) for the South African economy between 1986 and 1998.

The regression is acceptable in terms of statistical and econometric criteria. However, the instability of the coefficients shows that the sensitivity of investment to both interest rates and domestic demand has been falling over time, particularly since 1994 (as depicted in Figure 3).

\section{Figure 3 Coefficient stability of investment function}

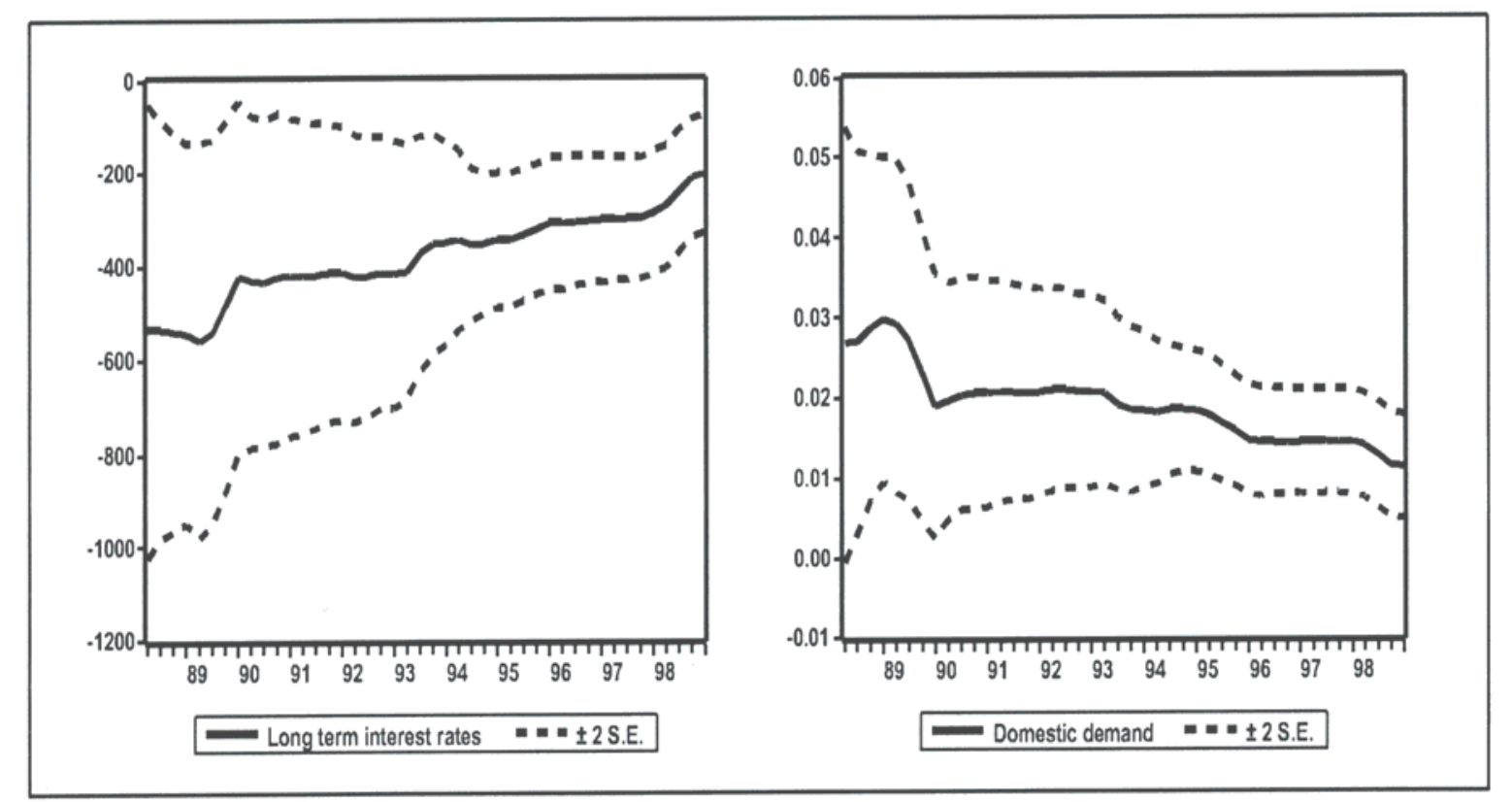

This is further evidence of the unequal globalisation (in respect of the impact on imports and exports) experienced in the South African economy. The relatively unfavourable investment environment, in the light of increased global competition, has resulted in this deterioration.

The low elasticity of private investment to domestic demand and interest rates, which constrains the longer-term growth potential in the economy, is cause for concern. It is indicative of the prevailing uncertainty among potential domestic investors, regarding their operating environment. This has led to merely marginal short-term adjustments in investment demand, to correspond with business cycle movements, in recent years. It is thus crucial for government to instil renewed confidence in the business community by introducing structural reforms. Only when distortions in local factor markets and tax structures are addressed and government creates a favourable, enabling environment for 
business, will investment horizons broaden and investment spending grow again.

Even though econometric models and yield curve analysis are useful in assessing the impact of interest rate changes on the economic structure, their power in predicting the magnitude and direction of swings in the business cycle is inferior and restricted to the use of short-term interest rates on their own. Whereas the econometric model tries to capture all possible linkages on the demand-side, yield curve analysis is useful in assessing the impact of interest rates on the economic structure, via its influence on the relative profitability of different sectors in the economy. Its power to predict the magnitude and direction of swings in the business cycle is inferior and restricted to the use of short-term interest rates on their own (Rothbard, 1970: 382; Mises, 1963: 536). The yield curve only has leading indicator properties because it incorporates the transmission lag of monetary policy. Furthermore, as yield curve analysis ignores the different interest rate elasticities of the individual GDP components, it is of little relevance for assessing the impact of interest rate changes on different types of investment on the various sectors in the economy and ultimately share prices. This shortcoming can be accommodated in a microeconomic framework, which is the topic of the next section.

\section{THE AUSTRIAN SCHOOL PERSPECTIVE TO THE IMPACT OF INTEREST RATES}

The conventional theory discussed above, suggests that lower interest rates could raise output levels in the economy via increased demand and higher potential production, following a higher level of investment. However, the macroeconomic analysis assumes investment to be homogenous. It therefore ignores the possibility, that a change in interest rates might have a different impact on different types of investment and thus cause divergent sector responses. The Austrian school addresses this shortcoming by adopting a microeconomic framework. What follows is based on Garrison's (2001) and Horwitz's (2000) models of the Austrian Business cycle. According to these authors, the focus of the Austrian school is on how a change in interest rates alters the structure of production in the economy. The starting point is the realisation that investment is not homogeneous. A single investment function, partly driven by interest rates, is therefore not capturing everything - certainly not the impact on different types of investment or different sectors. The heterogeneity of capitalistic methods of production must be considered to fully comprehend the investment decision and thus the impact of interest rates. The Austrian approach provides theoretical arguments for such an influence by relying on microeconomic principles of optimal investment allocation. The 
impact of interest rates, according to this theory, may be summarised by the following propositions:

- A change in interest rates alters the relative profitability of different types of investment - This argument is based on the differentiation of investment according to the length of the production process, as interest rates have a differentiated impact through the time dimension. Lower rates increase returns across all production processes, but they have the greatest impact on the most heavily time-discounted processes. At a higher interest rate, a shorter production process is therefore more profitable - and as interest rates fall, the profitability of long production processes will increase, relative to shorter production processes. Thus, as interest rates fall, the relative profitability of investment in long production processes will be higher. These should therefore attract more investment, relative to shorter production processes.

- $\quad$ Lower interest rates result in higher investment across all sectors - The increase in demand for investment goods implies that the capacity utilisation of sectors further away from final consumption will initially tend to increase more, relative to sectors closer to final consumption. As sectors with longer production processes thus experience a higher level of investment relative to shorter processes in the initial stages of the cycle, their capacity utilisation levels will fall later on in the cycle. The relatively lower investment in shorter processes, by contrast, will raise capacity utilisation in the more mature stage of the cycle.

- Lower interest rates induce differentiated levels of capacity utilisation, investment responses and complementary employment of labour in different sectors - The resource utilisation between sectors, as initially reflected by different capacity utilisation changes, is therefore altered by a reduction in interest rates. This is in addition to changes in response to relative factor costs, which is the more traditional implication of a change in interest rates on the relative utilisation of labour and capital.

- $\quad$ Expansionary monetary policy, as reflected by falling interest rates, will have a permanent impact on the economy's future performance as it affects the productive structure through the profitability of different investments - This will alter the production stock in the economy and, given heterogeneous capital and rather limited substitutability, output potential and its nature could be changed permanently. This approach, therefore, implies that a monetary shock will permanently alter the business cycle. Monetary policy is not neutral and there is no long-term deterministic trend around which GDP fluctuates. 
At this point it is useful to point out the significance of the above propositions as it relates to share prices. The implications are obvious: A fall in interest rates raises the demand for investment goods, from long production processes relative to shorter processes, which implies an initially greater response in earnings growth from companies involved in long processes. A higher level of capacity utilisation also raises the profitability of these firms as capital costs per unit of output fall and possible gains in economies of scale are materialised. Both these effects should thus enforce relatively stronger earnings growth for shares in sectors with long production processes. Both these effects require an initial improvement in capacity utilisation, either as a sign of improved profitability or as a sign of increased demand.

The empirical test, whether capacity utilisation of sectors with long production processes rises relative to that of sectors with short processes when interest rates fall, is therefore crucial. The significance of the empirical confirmation of this theory lies in the timing of earnings responses. Should the theory be confirmed, investors should give preference to those sectors with long production processes relative to sectors with shorter processes in the early stages of an interest-rateinduced upswing, as the former will experience superior earnings growth. This finding should be incorporated when assessing the outlook for earnings and share prices, as it represents a further influence by interest rates on the economy and ultimately share prices. Increased investment demand, higher capacity utilisation and the longer time-discount of future returns will cause stronger earnings growth in sectors with long production processes when interest rates fall. This has profound implications for investment behaviour.

The remainder of this paper is devoted to assessing the effectiveness of conventional economic analysis (the yield curve and basic econometric models) and the Austrian microeconomic perspective as tools to predict the impact of interest rates on the business cycle of the economy.

\section{THE YIELD CURVE AS A PREDICTOR OF THE IMPACT OF INTEREST RATES}

There are three economic arguments for using the yield spread as a leading indicator of economic activity:

The yield spread reflects the stance of monetary policy

According to this view, a low yield spread (in absolute terms) reflects relatively tight monetary policy. This is based on the economic theory that long-term interest rates are a reflection of expected future short rates plus a possible risk premium. Short-rates higher than long-rates would, 
therefore, suggest expectations of falling short-rates, implying prevailing tight monetary policy. A second theory supporting this interpretation is that short-rates tend to rise faster than long rates when monetary policy is tightened and, as a result, the yield spread declines (Buse, 1965).

(ii) The yield spread contains information on credit market conditions Long yields are the outcome of demand and supply in the bond market. Should the spread increase as a result of rising long-term interest rates, it could be a reflection of increased demand for funding and thus future real economic activity (Malkiel, 1962).

(iii) The yield spread reflects the direction of future inflation changes

Long-term interest rates are a reflection of future inflationary expectations. A narrowing of the spread will reflect a decrease in future inflation, if inflationary forecasts reflected by the curve are on average correct. This reasoning is linked to the first argument, as falling inflationary expectations cause a decline in expected future short rates (Fama, 1975).

All these arguments may be linked to the interplay of the business and interest rate cycles. During recessionary conditions, monetary policy will tend to loosen, resulting in falling short rates. As economic conditions respond with a lag, inflation (and thus long rates) will not follow immediately, thus leading to a steepening in the curve. As the economic recovery gains momentum, short rates will tend to stabilise while inflationary fears and thus long rates will tend to rise, resulting in a normal shape of the curve.

Finally, tighter monetary policy to restore balance in the economy will gradually induce a negative slope. Therefore, the spread of the yield curve gives an indication of the influence of monetary policy, and thus short rates, on future economic activity. The leading indicator properties are the result of the transmission lag of monetary policy. The three possible reasons for the leading indicator properties of the yield curve reflect the demand channel of interest rates. As will be discussed below, a more appropriate way of modelling, measuring and assessing this impact is through the use of an econometric model.

However, the yield curve is useful in assessing the Austrian approach. Any drastic change in the shape of the yield curve is a reflection of monetary policy. The extent of monetary stimulation may therefore be related to the steepness of the curve, which can be used as a measure of excessive monetary stimulation in the market-process approach. In essence, long-rates are considered as the true or natural interest rate in this case. 


\subsection{Empirical evidence}

Figure 4 shows the relationship between the spread of the yield curve (lagged four quarters) and GDP growth. It provides visual evidence that the spread of the yield curve could be a leading indicator of economic activity.

\section{Figure 4 Yield curve and GDP}

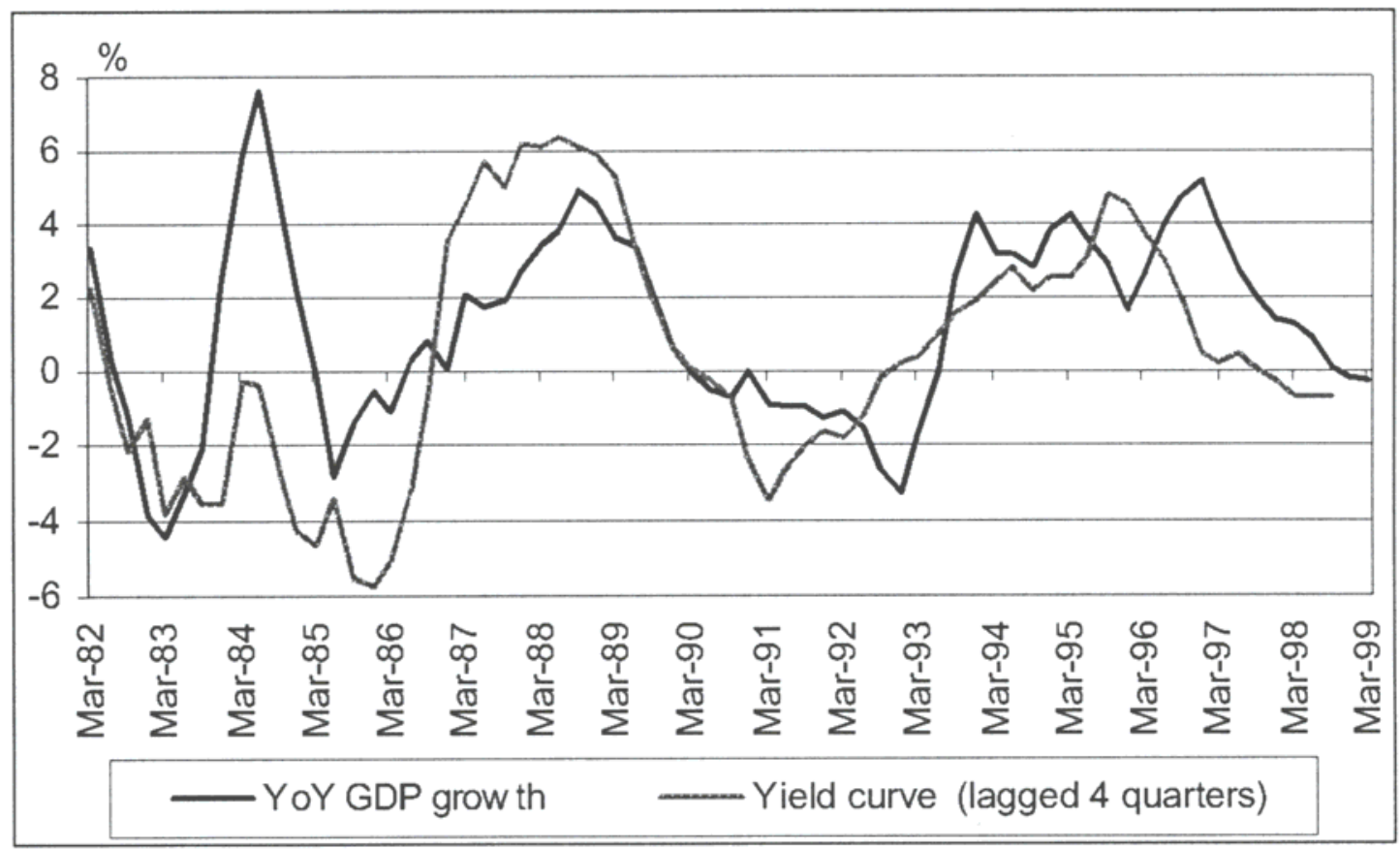

After numerous regression specifications were tested, it was concluded that a four-quarter lag of the yield spread provides the best explanatory power of economic activity, both in statistical and in econometric terms. The regression results are provided in Table 2 and Figure 5 below. However, a closer examination raises numerous concerns. Firstly, the coefficient of the above regression shows considerable instability. This is the result of aggregation, as the interest rate elasticities for individual GDP components differ. Secondly, the explanatory power regarding turning points in the economic cycle is limited.

While the $\mathrm{R}^{2}$ and the Durbin-Watson statistic might suggest that, it is also confirmed by the fact that the error term is a close reflection of the GDP growth trend. This is clearly evident from the goodness-of-fit in Figure 6. In addition, the yield spread is also a poor indicator of the magnitude of swings in the business cycle. 
Table 2 Regression of yield spread on GDP

Dependent variable is the percentage change in real GDP

Sample (adjusted): 1990:1 1998:3

Included observations: 35 (after adjusting endpoints)

\begin{tabular}{|l|c|c|c|c|}
\hline Variable & $\begin{array}{c}\text { Coeffic } \\
\text { ient }\end{array}$ & $\begin{array}{c}\text { Std. } \\
\text { error }\end{array}$ & $\begin{array}{c}\text { t- } \\
\text { statis- } \\
\text { tic }\end{array}$ & Prob. \\
\hline Constant & 0.007 & 0.003 & 2.228 & 0.033 \\
\hline $\begin{array}{l}\text { Spread of the yield curve lagged four } \\
\text { quarters }\end{array}$ & 0.107 & 0.021 & 5.099 & 0.000 \\
\hline R-squared & 0.44 & $\begin{array}{l}\text { Mean dependent } \\
\text { var }\end{array}$ & 0.01 \\
\hline Adjusted R-squared & 0.42 & $\begin{array}{l}\text { S.D. dependent } \\
\text { var }\end{array}$ & 0.02 \\
\hline S.E. of regression & 0.02 & $\begin{array}{l}\text { Akaike info } \\
\text { criterion }\end{array}$ & -8.04 \\
\hline Sum squared resid & 0.01 & Schwarz criterion & -7.95 \\
\hline Log likelihood & 93 & F-statistic & 26.00 \\
\hline Durbin-Watson stat & 0.41 & Prob (F-statistic) & 0.00 \\
\hline
\end{tabular}

Figure 5 Coefficient stability of regression of yield curve on GDP

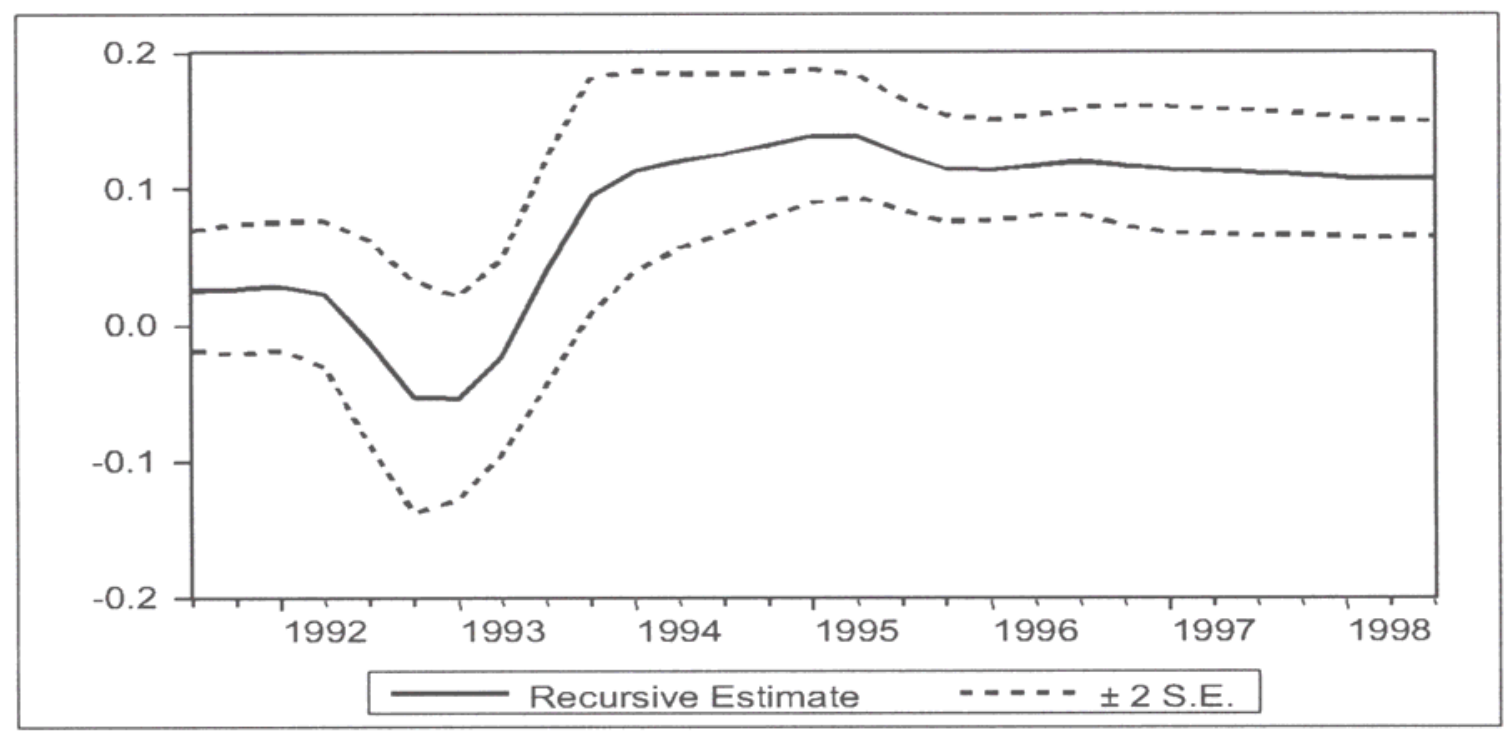




\section{Figure 6 Goodness-of-fit of regression of yield curve on GDP}

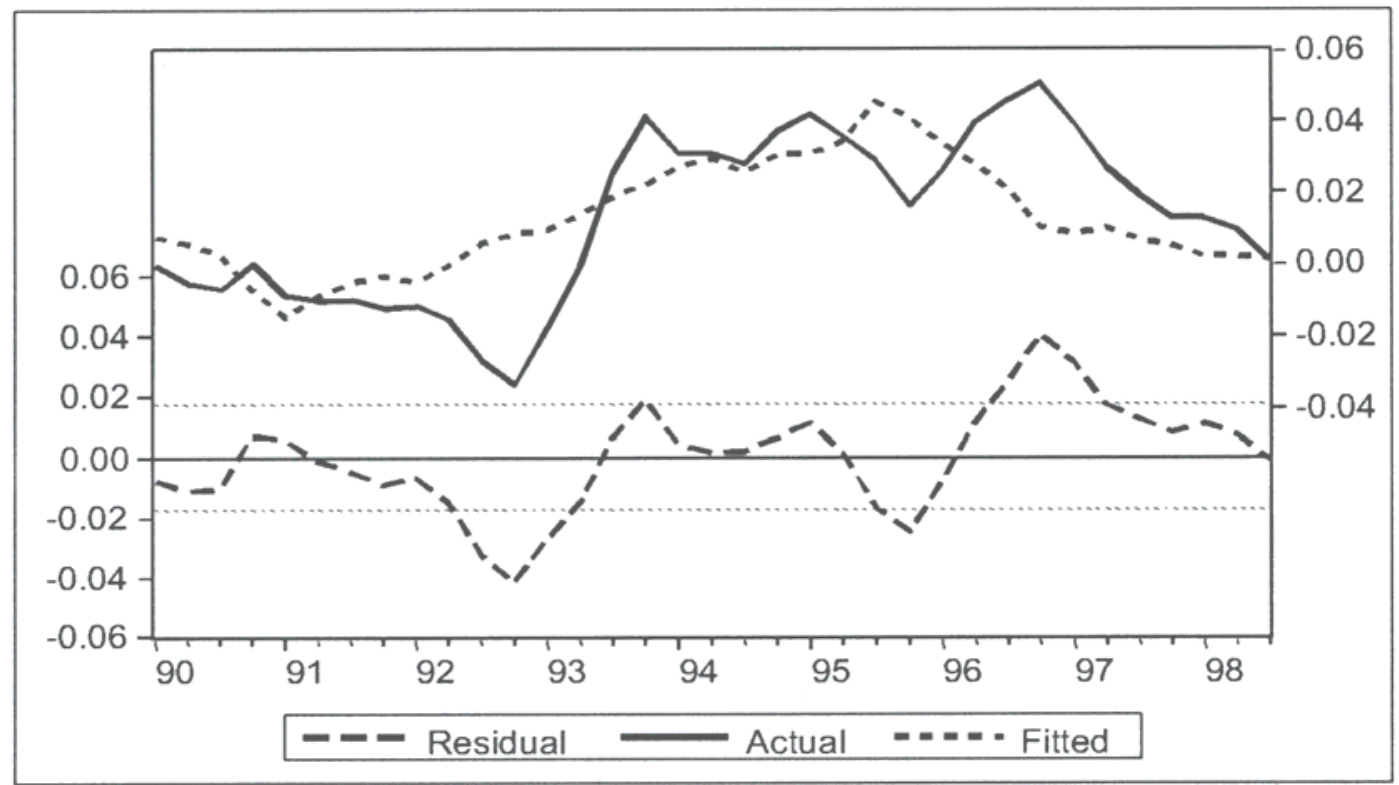

Substituting short-rates for the yield spread in the regression analysis does not reduce the explanatory power of the regression (shown in Table 3). The predicting power of the yield spread is therefore predominantly explained by movements in short-rates. This takes us back to conventional economic analysis. The coefficient of the short-rate in the regression is also much more stable than that of the yield spread.

Table 3 Regression of short-rates on GDP

\begin{tabular}{|l|c|c|c|c|}
\hline \multicolumn{4}{|l|}{ Dependent variable is the percentage change in real GDP } \\
\hline \multicolumn{4}{|l|}{ Sample (adjusted): 1990:1 1998:3 } \\
\hline Included observations: (35 after adjusting endpoints) \\
\hline Variable & $\begin{array}{c}\text { Coeffici } \\
\text { ent }\end{array}$ & $\begin{array}{c}\text { Std. } \\
\text { error }\end{array}$ & $\begin{array}{c}\text { t- } \\
\text { statis- } \\
\text { tic }\end{array}$ & Prob. \\
\hline Constant & 0.270 & 0.037 & 7.217 & 0.000 \\
\hline 3-months BA rate lagged by 4 quarters & -0.096 & 0.014 & -6.894 & 0.000 \\
\hline R-squared & 0.59 & $\begin{array}{l}\text { Mean dependent } \\
\text { var }\end{array}$ & 0.01 \\
\hline Adjusted R-squared & 0.58 & $\begin{array}{l}\text { S.D. dependent } \\
\text { var }\end{array}$ & 0.02 \\
\hline S.E. of regression & 0.01 & $\begin{array}{l}\text { Akaike info } \\
\text { criterion }\end{array}$ & -8.35 \\
\hline Sum squared resid & 0.01 & Schwarz criterion & -8.26 \\
\hline Log likelihood & 98 & F-statistic & 47.53 \\
\hline Durbin-Watson stat & 0.34 & Prob (F-statistic) & 0.00 \\
\hline
\end{tabular}




\section{Figure 7 Goodness-of-fit of regression short-rates on GDP}

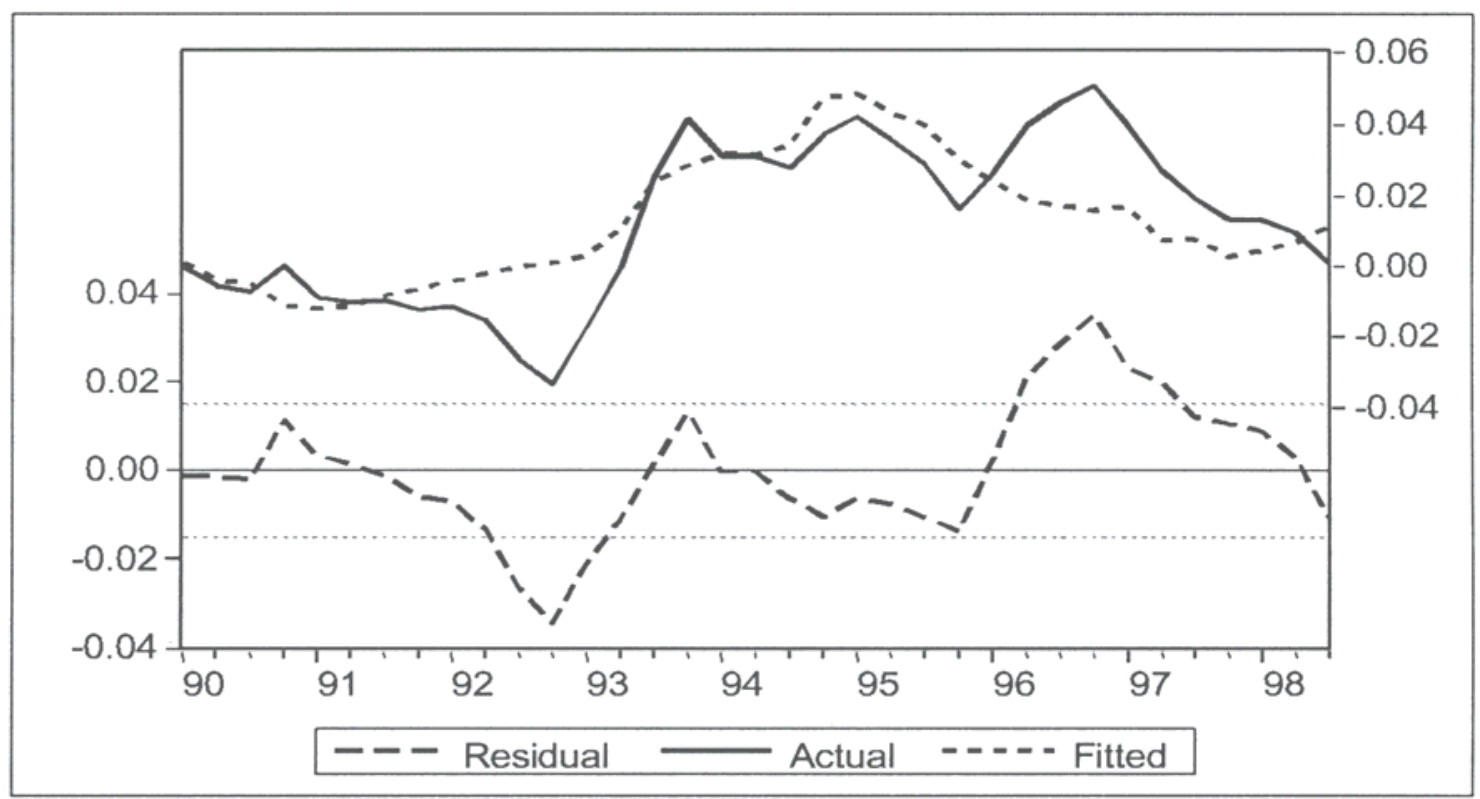

Figure 8 Coefficient stability of yield curve on GDP

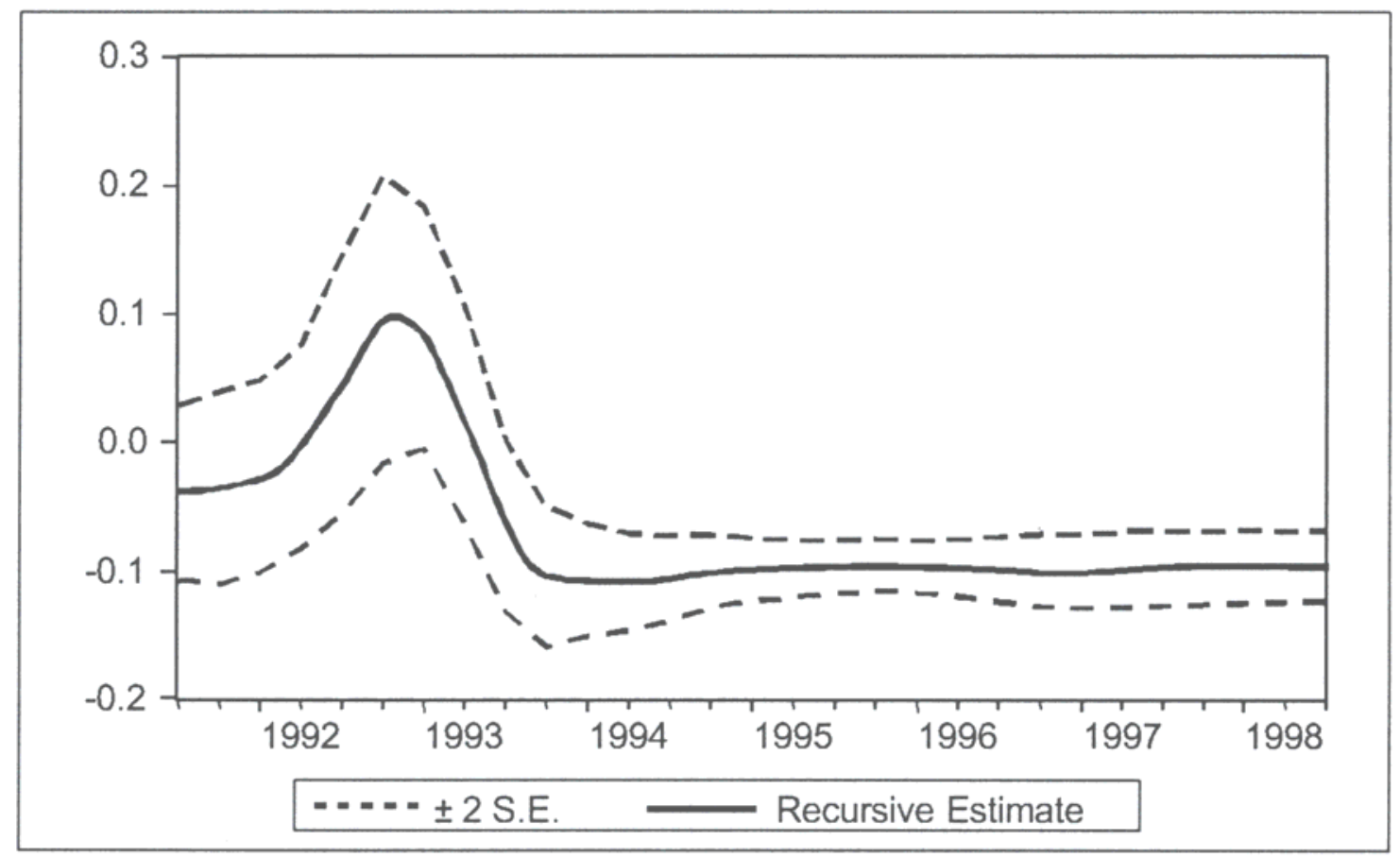

\subsection{Assessment}

Yield curve analysis has only limited information content, as it essentially reflects the transmission between a change in short-rates and its impact on GDP. Given that the composition of GDP and that the differing interest rate 
elasticities of its demand components are ignored, the analysis is inherently unstable and of little relevance in assessing the impact on different sectors of the economy - and ultimately share prices. Also, rather little can be learnt from determining how a change in short-term interest rates will impact on the shape of the yield curve - as an exercise to assess the impact of interest rates on the economy. The impact on long rates will still have to be determined, necessitating a comprehensive evaluation.

\section{THE USE OF AN ECONOMETRIC MODEL TO MEASURE THE IMPACT OF INTEREST RATES}

An econometric model provides a comprehensive assessment of the impact of interest rate changes on the economy, by modelling dynamics and simultaneous impacts. An attempt is made to approximate the structure of the economy and with it, the elasticities of all components of the economy with regard to interest rate changes. These include consumption, investment, exchange rates, the demand for money or credit and international capital flows. An econometric model separates the impact of long-term and of short-term interest rates on the economy, as well as the relationship between the two. A structural model also allows policy simulations to determine the impact of a particular monetary policy response or long-term interest rate shock. Top-down earnings forecast the need to capture all the demand-side aspects of interest rate impacts on sector-specific components of GDP or GDE. This can be accomplished only through the use of an econometric model.

\subsection{Policy simulations}

Numerous policy simulations have been carried out in South Africa, each with relatively complex sets of econometric models. All these simulations measured the impact of a change in short-term interest rates, and thus monetary policy, on the economy. Working papers by the South African Reserve Bank and the Bureau of Economic Research (BER) provide adequate literature in that regard (see for example SARB Occasional Paper No 11, July 1998). Differences in simulation results can be ascribed to different model specifications and assumptions made during simulation. There are many advantages of constructing econometric models. However, some of the most beneficial include the fact that the following impacts can be reported: 
Table 4 Impact of interest rate changes on the South African economy

\begin{tabular}{|l|c|c|c|c|}
\hline \multirow{2}{*}{ Variable } & \multicolumn{2}{|c|}{1999} & \multicolumn{2}{c|}{2000} \\
\cline { 2 - 5 } & Base & Simulation & Base & Simulation \\
\hline GDE Growth & -0.7 & -0.5 & 5.1 & 6.0 \\
\hline PCE Growth & $1.1 \%$ & $1.0 \%$ & $3.1 \%$ & $3.7 \%$ \\
\hline Current account (Rbn) & -2.3 & -2.8 & -12.0 & -16.0 \\
\hline $\begin{array}{l}\text { Net balance of payments Flows } \\
\text { (Rbn) }\end{array}$ & 34.4 & 34.5 & 24.7 & 21.0 \\
\hline Average long bond yield & 13.8 & 14.0 & 14.3 & 14.5 \\
\hline Policy shock: repo rate average & $\begin{array}{l}\text { 3 percentage points } \\
\text { lower }\end{array}$ & $\begin{array}{l}\text { percentage points } \\
\text { lower }\end{array}$ \\
\hline R/US\$ spot rate & 6.16 & 6.17 & 6.5 & 6.52 \\
\hline Inflation (Core) & 8.0 & 8.2 & 8.6 & 8.9 \\
\hline $\begin{array}{l}\text { Private non-residential fixed } \\
\text { investment growth }\end{array}$ & $-4.10 \%$ & $-4.10 \%$ & $9.20 \%$ & $9.60 \%$ \\
\hline
\end{tabular}

- $\quad$ The greatest impact of the monetary relaxation is felt in 2000 and beyond. This is in line with simulations of the South African Reserve Bank's (SARB) model and is the result of the transmission lag of monetary policy.

- $\quad$ The largely unaltered exchange rate forecast is due to the assumptions underlying the inherent strength or weakness of the exchange rate. With sizeable net capital inflows in both our simulations, the exchange rate remains predominantly driven by the assumption regarding its inherent strength or weakness.

- $\quad$ The demand pressure in the economy is predominantly felt through the current account, in line with the global integration of the economy. With the exchange rate remaining overall stable, pressure on import prices will remain subdued and core inflation only has a limited upward tendency.

- $\quad$ Long-term interest rates increase due to fears of inflationary pressures, lower net inflows and the fact that short rates are not imposed on long rates due to their omission from our equation explaining long-term interest rates.

- The simulation results are time-dependent. Over the forecast period, there are numerous components of gross domestic expenditure (GDE) that are entirely policy insensitive. These refer in particular to the demutualisation assumption for private consumption expenditure (PCE), which lowers the interest rate elasticity of PCE for the simulation period and the assumption on the sizeable residual, which lowers the GDE elasticity. 


\subsection{Assessment}

In virtually all models for South Africa, investment is treated as homogenous. Distinctions are generally made between private and public investment, as well as between residential and non-residential investment, but no distinction is made for the investment responses of different sectors of the economy to interest rate changes. And yet, microeconomic theory suggests that the impact of an interest rate cut on different sectors of the economy will differ (Baird 1982: 310-312). The final section attempts to test this hypothesis empirically for South Africa and to quantify the differentiated impact.

\section{QUANTIFYING THE IMPACT OF INTEREST RATE CHANGES ON INVESTMENT ACCORDING TO THE AUSTRIAN SCHOOL}

The theoretical analysis has shown that a change in interest rates causes a change in the allocation of investment resources, cumulatively in the structure of capital stock towards longer production processes.

As the positive monetary shock has its effect, the early expansionary phase may be characterised by a fall in short-term interest rates relative to long-term rates. Only later in the expansion will the rise in income and consumption demand, with the shortage in resources, raise short-term rates again. The change in the slope of the yield curve, therefore, captures the influence of monetary policy on the structure of production. This analysis also provides a complementary assessment of interest rate changes. It focuses on interest rates from the production side rather than giving the conventional interpretation regarding demand which, as pointed out earlier, is more appropriately assessed with an econometric model.

The following regression results confirm the relevance of the Austrian approach for South Africa. The model is based on Keeler's (2001) analysis. Capacity utilisation in heavy industries relative to light industries is modelled as a function of three key variables:

- The steepness of the yield curve - This variable reflects the stance of monetary policy.

- $\quad$ Potential output relative to actual - This variable measures the stage of the prevailing cycle of real economic activity

- Growth in money supply - This measures the amount of liquidity available to finance real economic activity.

To quantify the dynamic impact of an expansionary monetary policy on interest rates, economic growth and relative capacity utilisation, a vector autoregression 
(VAR) model was specified with the above four variables. Each variable had a lag length of three quarters. A VAR is essentially based on the principle that everything in the economy influences everything else. All variables feature in the equation and no specific structure is imposed. The following figures show the impact of a one-standard-deviation increase in money supply growth on the other three variables. The correctness of the direction of change is confirmed by the previous regression analysis, as well as by the theoretical discussion of the Austrian approach.

\section{Table 5 Regression results}

Dependent variable is capacity utilisation in heavy industries relative to light industries

Sample (adjusted): 1982:2 1998:1

Included observations: 64 (after adjusting endpoints)

\begin{tabular}{|l|c|c|c|c|}
\hline Variable & $\begin{array}{c}\text { Coeffici } \\
\text { ent }\end{array}$ & $\begin{array}{c}\text { Std. } \\
\text { Error }\end{array}$ & $\begin{array}{c}\text { t- } \\
\text { Statis- } \\
\text { tic }\end{array}$ & Prob. \\
\hline Actual relative to potential output & 0.810 & 0.217 & 3.733 & 0.000 \\
\hline Shape of the yield curve (-2) & 0.048 & 0.025 & 1.928 & 0.059 \\
\hline $\begin{array}{l}\text { 3 quarters moving average in M3 } \\
\text { growth }\end{array}$ & 0.376 & 0.139 & 2.701 & 0.009 \\
\hline Change in M3 velocity & 0.196 & 0.103 & 1.896 & 0.063 \\
\hline Dummy for 1998 & 0.020 & 0.011 & 1.890 & 0.064 \\
\hline R-squared & 0.456 & $\begin{array}{l}\text { Mean dependent } \\
\text { var }\end{array}$ & -0.006 \\
\hline Adjusted R-squared & 0.419 & $\begin{array}{l}\text { S.D. dependent } \\
\text { var }\end{array}$ & 0.020 \\
\hline S.E. of regression & 0.015 & $\begin{array}{l}\text { Akaike info } \\
\text { criterion }\end{array}$ & -8.328 \\
\hline Sum squared resid & 0.013 & \multicolumn{2}{|l|}{ Schwarz criterion } & -8.159 \\
\hline Log likelihood & 180.69 & F-statistic & 12.400 \\
\hline Durbin-Watson stat & 1.975 & \multicolumn{2}{l|}{ Prob (F-statistic) } & 0.000 \\
\hline
\end{tabular}

As can be seen from the impulse response functions below, an increase in the money supply leads to a steeper and positive yield curve, raises GDP growth relative to potential and increases capacity utilisation in heavy industries relative to lighter industries, in accordance with the theoretical discussion. 


\section{Figure 9 Goodness-of-fit}

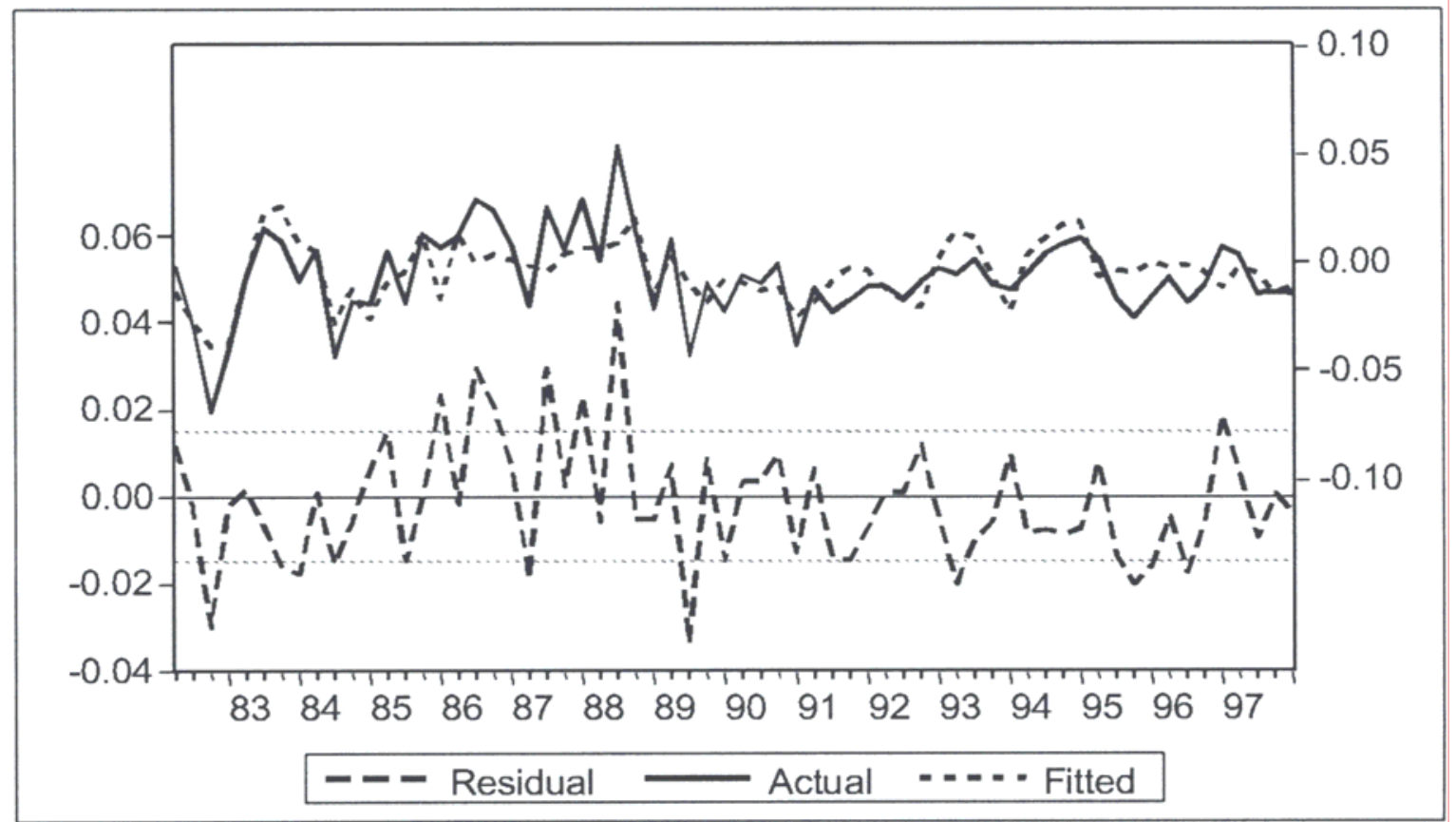

Figure 10 Impulse-response function of the yield curve

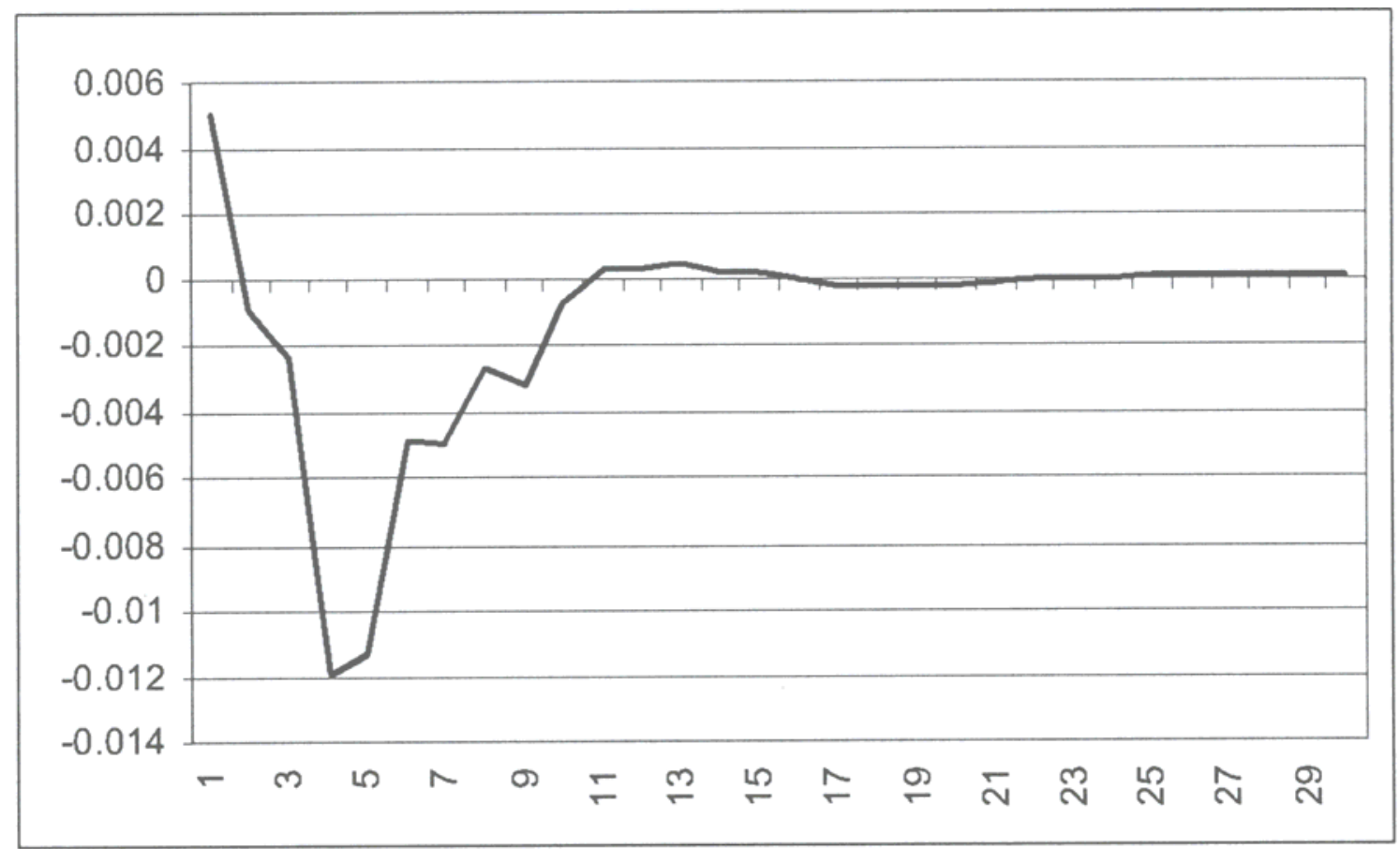




\section{Figure 11 Impulse-response function of relative capacity utilisation}

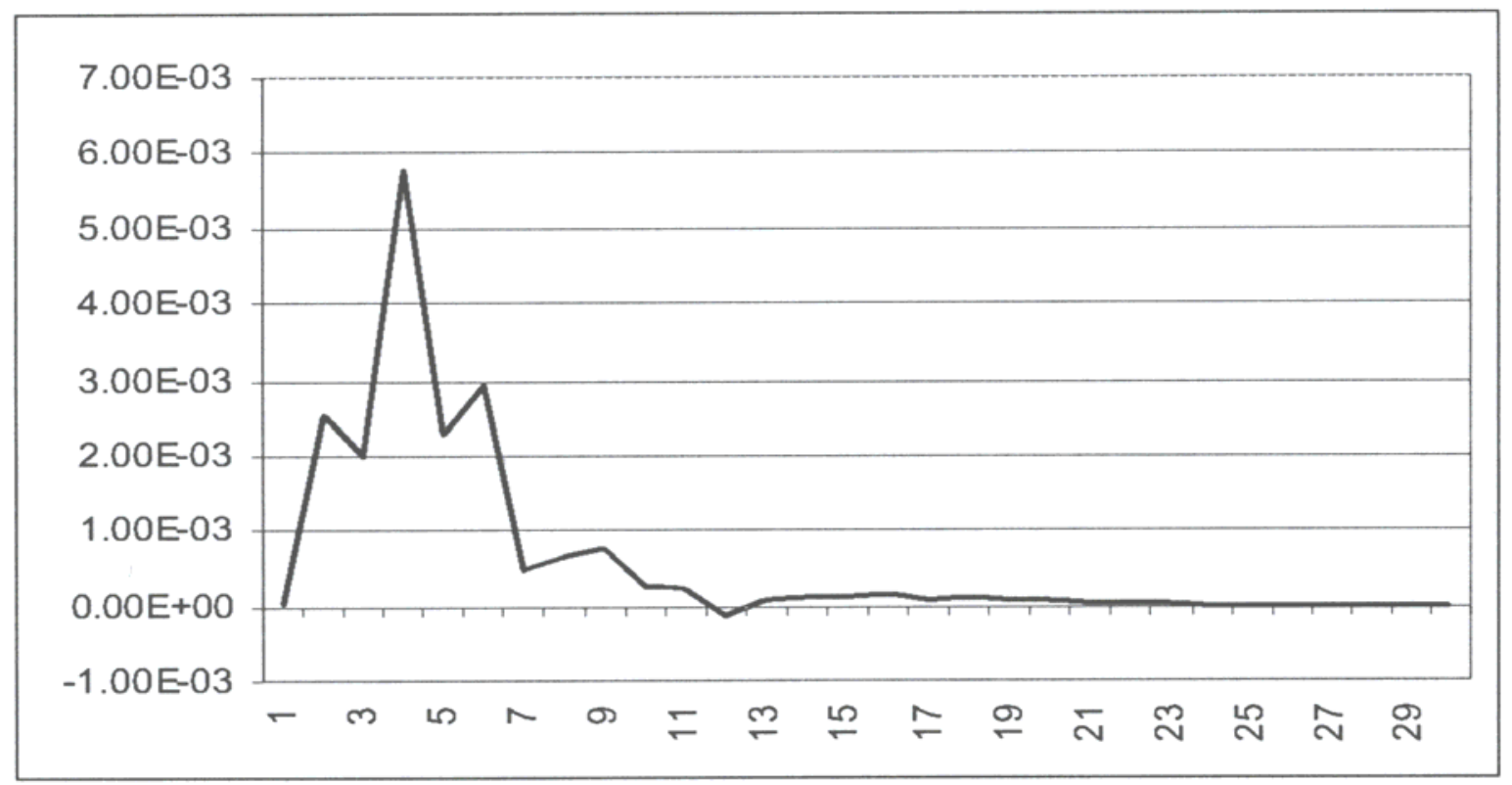

Figure 12 Impulse-response function of actual to potential output

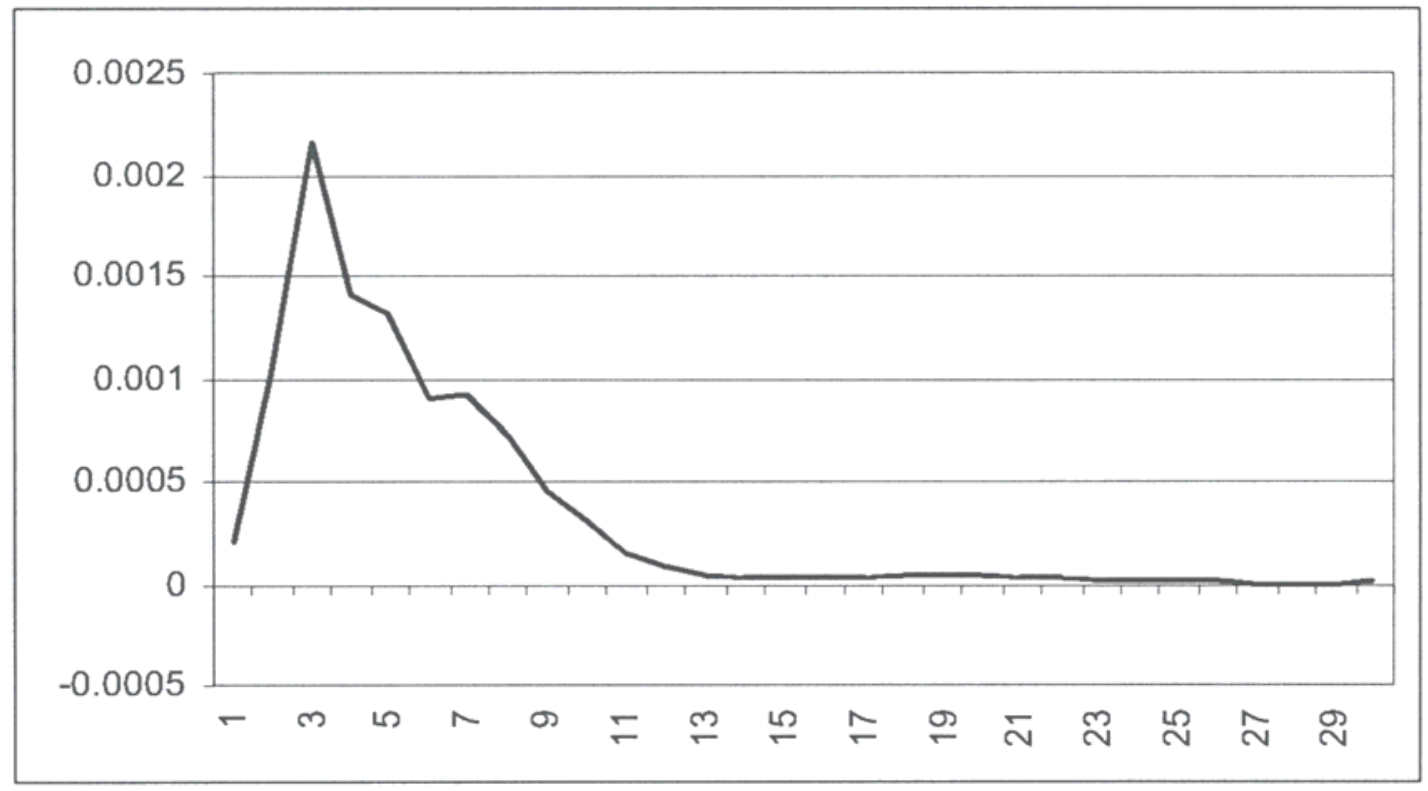

\section{CONCLUSION}

Demand-side analysis of the impact of interest rates on the economy is best done via an econometric model, to allow for the capturing of all linkages. The low elasticity of investment response to interest rates and domestic demand in South Africa constrains the level of output in the economy. Yield curve analysis is useful in assessing the impact of interest rates on the economic 
structure, via its influence on the relative profitability of different sectors in the economy. However, its ability to predict the magnitude and direction of business cycle swings is inferior to the use of short-term interest rates on their own. The yield curve only has leading indicator properties because it incorporates the transmission lag of monetary policy. Because yield curve analysis ignores the different interest rate elasticities of the individual GDP components, it is of little relevance assessing the impact of interest rate changes on different sectors in the economy and ultimately on share prices.

Empirical confirmation of the theory suggests that the profitability of heavy industries outperforms that of light industries in the initial stages of monetary easing, due to a rising demand for investment goods and a rise in capacity utilisation levels. Also, the further downstream an industry, the bigger the positive impact of a fall in interest rates, due to the longer time-discount of future returns. A comprehensive assessment of the impact of interest rates on sector earnings and ultimately share prices, therefore, has to take the impact of interest rates on the productive structure of the economy into account. It is essential to accommodate the changes in productivity or profitability that could result from a change in interest rates.

\section{REFERENCES}

1 BUSE, A. (1965) "The expectations hypothesis, yield curves and monetary policy” Quarterly Journal of Economics. November: 664-68.

2 FAMA, E.F. (1975) "Short-term interest rates as predictors of inflation", American Economic Review, 65: 269-82.

3 GARRISON, R.W. (2001) Time and Money: The Macroeconomics of Capital Structure, Routledge: London.

4 HORWITZ, S. (2000) Microfoundations and Macroeconomics: An Austrian Perspective, Routledge: London.

5 KEELER, J.P. (2001) "Relative Prices and the Business Cycle", Paper presented at the Southern Economic Association Annual Meetings in Tampa USA.

6 MALKIEL, B. (1962) "Expectation, bond prices and the term structure of interest rates”, Quarterly Journal of Economics, 76: 197-218.

7 MISES, L. (1963) Human Action. ( $3^{\text {rd }}$ rev. ed.) Contemporary Book, Inc.: Chicago.

8 ROTHBARD, M.N. (1970) Man, Economy and State, Nash Publishing Company: Los Angeles. 